\title{
Meslek Folkloru Bağlamında Çerçiler
}

\section{Nuray KOMSER*}

\begin{abstract}
ÖZ
$\mathrm{Bu}$ makalede sosyal bir grup olarak meslek folkloru bağlamında geleneksel mesleklerden çerçilik ve onun sözlü edebiyata yansımaları incelenmiştir. Çerçi, köy ve kasabaları dolaşarak seyahat eden gezgin esnaftır. "Herkese her şey" sunmak için at, araba ya da sırtlarına yükledikleri heybelerinin içine özenle yerleştirdikleri eşyaları köy ve kasabaları dolaşarak satmaya çalışan çerçiler, ürünlerini tanıtmak için "sözün büyü" sünden yararlanmıştır. Sözlü kültür ortamına adeta yenilik, eğlence ve heyecan getirerek zaman içinde kendi folklorunu yaratmış, atasözü, deyim, fikra gibi sözlü edebiyat türlerine de konu olmuştur. Bu makalede kaybolmaya yüz tutmuş geleneksel mesleklerden biri olarak "çerçilik" meslek folkloru bağlamında folklorun onları tanımladığınca ele alınmış, mesleğin sözlü edebiyata yansımaları örneklerle gösterilmiştir. Stereotipler, belli özelliklerin belli insanlarda bulunduğunu varsayan kalıplaşmış değer yargılarını ifade eder. Bu bağlamda anlatmalardan hareketle mesleği icra eden çerçilerin ve diğer cephesini oluşturan sözlü kültür insanının gözünden çerçi stereotipi ortaya konulmaya çalışılmıştır. Çerçilerin sandıkları, heybeleri, at ya da eşeklerinin çektiği tenteli arabaları günümüz marketlerinin, mağazalarının reyonlarıdır. $\mathrm{Bu}$ bağlamda değiş tokuştan süpermarketlere gelenekselin dönüşümü, mesleğin günümüz çağdaş yaşamında önemli yeri olan süpermarketlere, çok şubeli mağazalara esin kaynağı oluşu da çalışmada ele alınmıştır.
\end{abstract}

Anahtar Kelimeler: Meslek Folkloru, Çerçi Folkloru, Stereotip, Sözlü Anlatilar

* Dr. Kültür ve Turizm Bakanlığı, Ankara/Türkiye

E-posta: nuray.komser@kulturturizm.gov.tr

Makale Gönderim Tarihi: 24.04.2018* Makale Kabul Tarihi:19.09.2018 


\section{ABSTRACT \\ Pedlars In The Context Of Occupation Folklore}

In this study; being a pedlar, as it is one of the traditional occupations in the context of occupation folklore in a social group, and its reflections on oral literature are analyzed. Pedlar is an itinerant merchant that wanders towns and villages. Pedlars who elaborately place their wares into the bags on their backs, horses or carts in order to "present anything to anyone", and sell the wares by wandering around towns and villages, take advantage of the "magic of word" for introducing their products. They created their own folklore in oral culture by adding innovation, humour and enthusiasm in time and became a subject to oral literature types such as proverbs, idioms and anecdotes. In this article, being a "Pedlar" is discussed in the sense of being one of the traditional occupations, that is sinking into oblivion, in the context of occupation folklore as much as folklore describes it, and its reflection on oral literature is shown by examples. Stereotypes describe cliche value judgments which considered as some particular people have some particular characteristics. In this context, pedlar stereotype is tried to be indroduced in the perspective of pedlars who perform this work and oral culture people on the other side of this relation. Chests and bags of the pedlars and awninged carts that are pulled by horses or donkeys are the sections of today's markets and stores. In this context, transformation of traditional from bartering to supermarkets and of occupation to supermarkets, which are in very important point of contemporary life, and its becoming a guiding spirit to chain marketing are discussed.

Keywords: Occupation Folklore, Pedlar Folklore, Stereotype, Oral Narrative 


\section{Giriş}

Tarihi süreç içerisinde folklorun tanımı tüm dünyada olduğu gibi 1 Türkiye'de de değişmiştir. 19.yy'da köyde ve kırsalda yaşayan insanların kültürlerinin incelenmesiyle başlayan folklor çalışmaları son yıllarda öne sürülen birtakım görüşler ile farklılık göstermiş, böylelikle folklorun çalışma alanına bakış açısı da değişmiştir. Başta Alan Dundes'ın "Halk en az bir ortak faktörü paylaşan herhangi bir insan topluluğudur.”(Dundes, 2006: 16) söylemi halkın kırsal alanda yaşayan köylü tanımlamasına yeni bir bakış açısı getirmiştir. Bu tanım daha sonra yapılacak olan grup folkloru çalışmalarının da adeta temelini atmıştır. Folklorun sosyal gruplar arasında da ortaya çıkabileceğine Dan Ben Amos'da dikkat çeker (2006:35). Ona göre bir grup bir aile, bir sokak çetesi, bir oda dolusu fabrika işçisi, bir köy, hatta bir kabile olabilir.

Meslek folkloru, "çalışma grubundaki üyelik ve konumları belirlemede kullanılan, gayri resmi olarak öğrenilmiş adetler, beceriler ve anlatılara özel vurgu yapılan anlatımlı çalışma alanı kültürü” (McCarl, 1996: 1089'dan aktaran Aça, 112: 2015) olarak tanımlanmıştır. Meslek folkloru bağlamında bugüne kadar dünyada ve ülkemizde pek çok çalışma gerçekleştirilmiştir. Bu bağlamda "Meslekler ve çalışma hayatıyla ilgili folklor araştırmaları, öncelikle kırsal alanlardan başlayıp giderek şehirlere ve modern dünyaya doğru genişlemiştir." (McCarl, 1986: 71'den aktaran Duymaz ve Şahin, 2010:104-105) Meslek folkloru köyden kente geleneksel ya da güncel meslekler ile mesleklerin icra biçimlerini, meslek etrafında şekillenmiş sözlü kültür unsurlarını kapsamaktadır. Örneğin, mesleğe kabul törenleri, inanışlar, fikralar, hikâyeler, efsaneler, halk şiiri örnekleri, meslekle ilgili atasözü, deyim ve kalıp sözler ile mesleklerin özel dilleri gibi pek çok konu meslek folkloru altında incelenmektedir. Bu bağlamda Türkiye'de çok sayıda mesleğin var olduğu ve bu mesleklerin de kendilerine özgü folklorik değeri bulunduğu söylenebilir.

Çalışmada çerçiler, toplumsal yapıda meslekleri doğrultusunda bir araya gelmiş grup olduğundan folklorun özel bir alanı olan meslek folkloru kapsamında ele alınmıştır. Günümüzde çerçilik mesleği yok olmaya yüz tutmuş olduğundan sözlü kaynaklar Tokat ilinde mesleğini sürdüren (modern ulaşım araçlarıyla) çerçiler ile çoğunlukla belli bir dönem sözlü kültür ortamında yaşamış, çerçi kültürünü bilen, geleneksel ticaret biçimini deneyimlemiş kişilerden oluşmaktadır. Bununla birlikte yazılı kaynaklardan da yararlanılmıştır. Çalışmada ilk olarak çerçilik mesleğinin tanımı, kapsamı ve özellikleri ile ilgili bilgilere yer verilmiştir. İkinci olarak, meslekle ilgili 
anlatılan/söylenen "deyim, atasözü, fikra" gibi pek çok sözlü kültür unsuruna bir başka ifadeyle mesleğin anlatmalardaki yansımalarına değinilmiş ve anlatmalardan hareketle çerçi stereotipi tespit edilmeye çalışılmıştır. Makalenin son bölümünde ise değiş tokuştan süpermarketlere mesleğin değişimi, dönüşümü değerlendirilmiştir. Çalışma maddi ve manevi kültürel değerlerin kayıt altına alınmasının yanı sıra çerçiliğin kültürel yapıdaki içerik, bağlam ve işlev özellikleriyle gelenekteki konumunu ve önemini göstermesi bakımından önem taşımaktadır.

\section{Babadan Oğula Ustadan Çırağa Çerçilik: Tanımı, Kapsamı ve Temel Özellikleri}

Geleneksel ticaret biçimi olan çerçilik ile ilgili sözlüklerde pek çok tanımla karşılaşmak mümkündür. Türkçenin Etimoloji Sözlügünde çerçi şöyle tanımlanır: "Moğ. Car (ses, bildiri, haber) dan çar/ çı /çerçi gerçek anlamı buyruk ulaştıran, bir yerden bir yere haber götüren, haberci. Anlam değişmesi yoluyla köy köy dolaşıp öteberi satan, gezici satıcı” (Eyüboğlu, 1995: 140) Osmanlı Tarih Deyimleri ve Terimleri Sözlüğü' nde çerçi için "her nevi ufak tefek eşya satan ve ekseriya para ile satmayıp başka mallarla değiştiren gezginci esnaf hakkında kullanılır bir tabirdir." (Pakalın, 1971: 116) denilmektedir.

İstanbul Ansiklopedisinde, Osmanlı İmparatorluğu Döneminde çerçiler ile ilgili en eski kaynağın Evliya Çelebi'nin "Seyahatname" adlı eseri olduğu ve Evliya Çelebi'nin eserinde çerçileri "esnaf-1 attaran-1 seyyaren" olarak tanıttığ 1 bilgisi yer almaktadır. Evliya Çelebi, İstanbul'da 300 çerçi bulunduğunu ve çerçilerin pirinin Abuzeddin Gaffari olduğunu söylemektedir. Aynı eserde çerçi şöyle tanımlanır: "Çerçiler ellerindeki şeyler içinde cemi edeviye mevcud olub etrafa çocuk oyuncakları dizub ordu esnafi arasında çerçi ha! diye gezerler."(Koçu, 1958: 3848) Osmanlı döneminde Şehrengiz türünde yazılmış ve "Hübannamei Nevada" adını taşıyan manzum mecmuada çerçi civanı şu beyitlerle övüldüğü belirtilir:

Çerçi civanlar olsa da yırtık Nani muhabbete olurlar katık Çeküb hane ye bir bahane ile Saydı asen anın zer dane ile Envai metai içre o şahın Tiryaki valsın al virüb günahım (Koçu, 1958: 3848) Osmanlı döneminde Şehrengiz türünde yazılmış ve "Hübannamei Nevada" adını taşıyan manzum mecmuada çerçi civanı şu beyitlerle övüldüğü belirtilir:

Çerçi civanlar olsa da yırtık

Nani muhabbete olurlar katık

Çeküb hane ye bir bahane ile 
Saydı asen anın zer dane ile

Envai metai içre o şahın

Tiryaki valsın al virüb günahım (Koçu, 1958: 3848)

Tokat ve çevresindeki illerin köy ve kasabalarında çerçilik yapan H. Salman baba mesleği olduğunu söylediği çerçiliği şu şekilde tanımlar: " Çerçi; para yerine bazı şeylerle (buğday, yün, yumurta gibi) takas ederek ticaret yapan, köy ve kasabalarda at, eşek, at arabası ya da motorlu araçlarla mallarını ulaştıran kişidir; yaptığı işe ise çerçilik denir.”(K1)

Geçmişten günümüze varlık gösteren çerçilere eşek ya da katırlarına yüklediği eşyaları yere sererek köylüye sunmasından dolayı sergici, yaymacı, dökmeci; günümüz bakkallarında ya da marketlerinde bulunan hemen hemen tüm malları bir heybe ya da sandık içinde toplayıp köy köy dolaştıkları için gezgin esnaf, gezgin bakkal, seyyar satıc1; sattıkları malları çığırtkanlık yaparak duyurdukları için seyyar bezirgân denilmektedir. Bunların dışında Anadolu köy ve kasabalarında üzeri beyaz çadır ile kaplanmış ve genellikle tek at tarafından çekilen at arabalarını bir bakkal gibi tanzim ederek çerçilik yapanlara da rastlanılmıştır. Bunlara da genellikle "çerçi” denilmektedir.

Geleneksel ticaret biçimi olan çerçilik yıllardan beri uygulanan bir ticaret yöntemidir. Mesleğin ilk defa kim tarafindan, nerede ve ne zaman uygulandığı bilinmese de kökeninin şu an bile çerçiliğin olmazsa olmaz dinamiklerinden olan "takas ticareti” ne uzandığı söylenebilir. Etnolog ve sosyologlar Afrika'da ve Amerika'da mal değişiminin en eski şekillerini araştırmışlar ve evrimin en alt basamağında yer alan oymakların eski göreneklerinin verdikleri isimleri belirlemişlerdir. Sedillot, çalışmasında Amerika ve Afrika'daki mal değişimine: "Moriolar buna 'toongo', Kuzey Amerikalılar 'potlaç', Troboh adasında 'kula' ve daha başka oymaklarda 'nagnapa' veya 'taussa' ( Sedillot, 2005: 14) denildiğini belirtir. Öyle görülüyor ki ticaret ilkeller döneminden sonra değişmiş ve gelişmiştir. İnsanoğlu ticaretin içine konuşmayı, el kol hareketlerini, yeminleri, parayı sokmuştur. Tarihi süreç içerisinde farklı coğrafyalarda, farklı adlarla ve farklı gerekçelerle yaşatılan takas ticareti zamanla evrilerek "çerçilik" mesleğin doğmasına ortam hazırlamı̧̧ır.

Kaynak kişilerden alınan bilgilere göre kırsal nüfus oranının fazla olduğu dönemlerde yoğun olarak sürdürülen çerçilik mesleğine başlama yaşı genellikle on- on ikidir. Çerçilerin meslekte başarı sağlamaları pek çok özel bilgi gerektirmektedir. Bu bilgiler ise geleneksel aktarım yöntemleriyle babadan oğula, ustadan çırağa aktarılmaktadır. Köy ve kasabaları dolaşan 
çerçiler, yolculuk süresi uzun olduğundan, bir yardımcıya ihtiyaç duymaktadır. $\mathrm{Bu}$ yardımcı genellikle aileden biri olup çoğunlukla da çerçinin oğlu olmaktadır. Çerçinin yanında mesleğe çırak olarak başlayanlara "çömez" adı verilmektedir. Yiğit, mesleğin genel özellikleriyle ilgili şöyle söyler:

$\mathrm{Bu}$ daha ziyade bir görenek işidir. Herkes birbirine bakarak bu işe atılabilir. Çıraklık devri uzun ve çıraklık için lazım olan masraf çok olmadığından hiç kimse çerçiliğe başlamakta tereddüt etmez. Babasıyla ya da yakın akrabasından biriyle ilk defa yabana çıkan çocuk ikinci defasında çerçi olarak bir gruba katılabilir (Yiğit, 1945: 508).

Çerçilerin sözlü kültür ortamına getirdikleri ürünler genel olarak iğne, iplik, naylon ayakkabı, naylon terlik, şeker, düdük, balon, sürme, pazen, basma, lavanta, çengelli iğne, helva, leblebi, keçiboynuzu, tarak, ayna, tütün kâğıdı, topaç, toka, bilezik, mendil, çeşit çeşit tesbih, seccade, nazar boncuğu, sakız, oyuncak bebek, naylondan yapılan tabak, leğen, halk hikâyesi, el kremleri gibi pek çok üründen oluşmaktadır. Bununla birlikte cumhuriyetin kurulduğu ilk yıllardan 1960'lı yılların ortalarına kadar masal, fikra, destan, hikâye gibi pek çok halk anlatısı olan kitapları, yayımları köylere getirmişlerdir. Çerçiler, köy ve kasabalarda halk hikâyelerini, destanları ve masalları köylüye tanıtarak kitapların içeriklerini meraklılarına özetlemişlerdir. Böylelikle halk kitaplarını en ücra köşelere kadar ulaştırarak kültür taşımada elçi görevini üstlenmişlerdir. Çocukluk yıllarını köylerinde geçiren kaynak kişimiz çerçinin getirdikleriyle ilgili şöyle söylemektedir:

1950’li yıllarda sadece kitap getiren çerçiler gelirdi köyümüze. Mahmut ile Yaralı Ceylan, Elif ile Garip, Asuman ile Zeycan, Aslı ile Kerem, Ferhat ile Şirin, Köroğlu getirdikleri kitaplardandır. Bu kitapları biz çocuklar yumurta karşılı̆̆ında çerçiden alırdık. Çerçiden aldığımız kitapları dönüşümlü olarak okurduk. Bu kitaplar, köyde, o yıllarda biz çocuklar için en heyecanlı eğlence kaynağıydı. Başka dünyalara bu kitaplarla yolculuk yapardik. (K2)

Çerçiler sözlü kültür ortamına gelişlerini kendilerine özgü seslenişleriyle duyurmaya çalışmışlardır. Örnek bir sesleniş şöyledir:

Boncuk var

Makara var

Düdük var 
Naylon misiraları var

Çerçi

Para alirim

Lastik alırım Çerçi (K3)

Çerçiler sandıklarını dolduran veya heybelerini kuşatan mallarının yanında önemli bir değer daha getirmişlerdir: Haber. Kitle iletişim araçlarının yaygın olmadığ 1 dönemlerde özellikle köylerde ve yaylalarda yaşayan topluluklar için çerçi haber kaynağ olmuş radyodan ve televizyondan habersiz olan kırsal kesim insanı dünya ile ilişkisinde çerçiyi bir köprü olarak görmüştür. Çerçiler, bu haber verme özellikleriyle de adeta köylünün her türlü ihtiyacını karş1layan konuma ulaşmıştır. Bu haberler ülkede ve dünyada olup biten olaylar hakkında olabileceği gibi kimi zaman da çevre köylerde olan olaylar hakkındadır. Çerçilerin haber ulaştırma özelliği pek çok halk hikâyesine de yansımıştır. Örneğin, Yazıcıoğlu ile Senem Türkülü Hikâyesi’nde ${ }^{1}$ görüldüğü gibi birçok halk hikâyesinde çerçiler, âşıklar arasında haber getirip götüren önemli kişiler olarak yer almışlardır. Çerçilerin haberci özelliği, günümüz teknolojisinin kırsala kadar ulaşmasıyla yitirilmiştir. Çerçilerin sözlü kültür ortamına gelişleri ve getirdikleriyle ilgili Çelik şöyle söyler:

Giyim kuşam başta olmak üzere birçok alandaki yenilikler onların vasıtasıyla köylere taşınıyor, dış dünyadaki değişmeler ve gelişmeler de onlardan öğreniliyordu. Bunların, köylünün ve özellikle köy kadınının düşünce ufkundaki genişlemede önemli katkıları olduğu muhakkaktır. Bütün bu özellikleriyle onları köylerdeki modernleşmenin ilk elçileri sağmak mümkündür. (Çelik, 2007: 291)

Bu bağlamda kırsal nüfusun fazla olduğu dönemlerde çerçilik mesleğinin, W. Bascom'un folklorun dört işlevini sıraladığı görüşlerine uygun olarak, sözlü kültür insanının "hoş vakit geçirme, eğlenme ve eğlendirme işlevi”, "toplumsal kurallara ve törelere destek verme", "eğitim ve kültürün genç kuşaklara aktarılması", "toplumsal ve kişisel baskılardan kurtulma” (Bascom, 2010: 78-81) işlevlerini yerine getirdiği söylenebilir.

\section{Çerçilik ile İlgili Anlatmalar ve Anlatmalardaki Çerçi Stereotipler}

Sözlü kültür unsurları çerçi folklorunun önemli bir parçası olarak dikkati çekmektedir. Çünkü kimi inanışları ve gelenekleri bildiren deyimlerin, atasözlerinin, nazlatmaların ve fikraların çerçilik folkloru etrafında 
şekillendiği söylenebilir. Müşteri kitlesini çoğunlukla kadınların ve çocukların oluşturduğu çerçi ile yapılan alışveriş, aşağıdaki örnekte görüldüğü gibi, annelerin çocuklarını oynatırken söyledikleri nazlatmalara konu olmuştur.

Lilili gızım lili li

Çerçiler gelmiş boncuğu çok

Aradım gızıma ilağıyı yok

Her rengi var turuncusu yok

Lilili g1zım lili li (K4)

Meslek ile ilgili anlatmalar çerçi folkloru etrafında oluşan, sözlü kültür aracılığ birlikte çerçi folklorundaki stereotipleri de göstermektedir. Stereotip "bir grup kişiye atfedilen özellikler bütünü (Bilgin, 1996: 98) olarak tanımlanmaktadır. Wenzel'e göre ise (1978: 28) "Stereotip, bir toplumsal grubun ya da bireylerin üyesi olduğu grubun kanaatinin dişa vurumudur. Stereotip nedensiz basitleştirme tarzı içinde, duygusal değerler ile bir kişinin belirli karakteristikler ve davranışları ile bir gruba normatif eğilimin genel ifadesinin mantıksal biçimidir." (İmançer, 2004: 133) Nitekim stereotiplerin oluşumu, bireylerin kolektif durumlarıyla, kimlikleriyle ilişkilidir. Çoğunlukla kişilerin meslek grubuna aidiyetleri neticesinde elde ettikleri bir durumdur. $\mathrm{Bu}$ bağlamda çerçilik mesleği ile ilgili anlatılan fikralarda ortak bir sterotip belirlemek mümkündür.

Aşağıda çerçi ile kadınlar arasındaki alışverişte yaşanan çekişmeli ilişkiyi gösteren iki farklı fikra şöyledir:

Kadın çerçiden bir yorgan iğnesi ister. Çerçi iğneyi verir. Kadın iğneyi evirip çevirdikten sonra sorar; Kaç kuruş? Çerçi cevap verir: Beş kuruş. Kadın cin gibidir.(!) Çerçinin kendisini aldatmaya çalıştığını anlar. "Geçen geldiğinde Ayşe'ye on kuruşa satmışsın bana da on kuruşa verirsen alırım” der. (K5)

Benzer bir fikra yine şöyledir:

Çerçi köye gelmiş. Köy kadınları çerçinin başına toplanmışlar. Alı̧veriş yapıyorlarmış. Aldanmamak için de çerçi ile sıkı pazarlı̆ga tutuşmuşlar. Köyden bir hanım gelmiş ve torunu için yalancı meme alacakmış. Çerçiye fiyatını sormuş. Emzikler kaç kuruş? Çerçi kırk kuruş demiş. Hanım bilgiç bilgiç birazda sinirli sinirli karşı çıkmış çerçiye: Biz parayı sokaktan toplamıyoruz 
dün gelen çerçi elli kuruş istedi sen kırk kuruş istiyorsun. Tövbe almam beklerim. Çerçi şaşırmış. Sağa sola bakmış; pahalı söylediği için utanmış mahcup mahcup cevap vermiş: Kusura bakma bacım, hesaplarken yanılmışım. Cahilliğgimi bağışla. Hadi sen de elli kuruş ver. Böylece pazarlık tatlıya bağlanmıştır. (K3)

Her iki fikrada da sözlü kültür ortamında yaşayan ve alışverişi çerçiden yapan kadınların, modern ticaret anlayışından (paradan) habersiz oluşları mizahi bir dille yansıtılmaktadır. Yukarıda verilen her iki fikra örneğinde de benzer bir biçimde çerçi uyanık, kurnaz, hazırcevaptır. "İnsanlar gerek yaşadıkları deneyimleri ve gerekse kendi kişilik ve kimlikleriyle ilgili pek çok şeyi dışa vurmaya ve anlatmaya çalıştıkları sırada fark ettiklerinden anlatıcılar anlatı sürecinde gösterimlemek istedikleri kimliğe ters düşen bazı bilgileri dışarıda bırakabilir veya abartabilir" (Kaderli- Yapıc1, 2012: 215). Bu bağlamda fikralarda çerçi ile yapilan alışveriş sırasında öne çıkarılan, alıcı ve satıcı arasındaki ilişkide alt eden kişinin çoğunlukla çerçi olduğu görülmektedir. Aşağıda verilen çerçi fikrası da çerçi benzer steoretip özellikler göstermektedir.

Eskiden buralara çerçi çok gelirdi. Katırlarında ya pekmez olur, ya da üzüm olurdu. Bu dağ köylerine buğdaydık, arpalık satar giderlerdi. Birinde pekmezin içine bir çekirge düşmüş. Çerçinin haberi yok. Pekmezi tartarken bakmış ki içinde koskoca bir çekirge. Hemen parmağına doladığı gibi ağzına atmış. Pekmez alanlardan biri bunu görmüş ama ne olduğunu anlayamamış. Herhalde değişik bir pekmez türü diye içinden geçirerek, ben de isterim diye tutturmuş. Çerçi adamın yüzüne bile bakmayarak; o binde bir, o binde bir demiş. (Dokuzoğlu; 2000: 33).

Yukarıdaki verilen fikrada da çerçi kendisine atfedilen stereotip olarak yine kurnaz, uyanık ve hazırcevaptır. Aşağıda verilen çerçi fikrası bu bakış açısıyla okunabilir: ${ }^{2}$

Temel çerçi köyde bit ilacı satıyormuş. Alanlardan biri 'nasıl kullanacağız?' diye sormuş. Çerçi cevap vermiş; 'Biti yakalayacaksın, sırtüstü yatıracaksın, bacaklarına sağa sola ayırıp ilacı karnına damlatacaksın.' Adam 'Yok yahu! O kadar şeyi yapana kadar biti basar öldürürüm.' demiş. Çerçi 'Eee, öyle de olur!'

Bununla birlikte mesleğin atasözü, deyim ve kalıp sözler içinde kullanımına bakıldığında gözlemlerimizi destekleyen birçok örnek bulabiliriz: Çerçi "Çerçi yükünden yemez" (K3) ve "Çerçi başındakini satar" (Eyüboğlu, 1973: 58) atasözlerinde uyanık, "İtin ürümesiyle çerçi eşeğini koyup kaçmaz" (K1) 
da cesur, gözü pek; "En iyi çerçi sesini en iyi duyurandır"(K6), "Eşek anırtmaz, çerçi çă̆ırtmaz" (Aksoy, 2004: 116), "Çerçi çağırma eşek bağırma bizim gelin yerikliyi” (Aksoy, 2004) atasözlerinde çığırtkan, "Eşeğini övmeyen çerçi olur mu" (Eyüboğlu, 1973: 95) , "Eşeğini övmeyen ve eşeğini dövmeyen çerçici olamaz" (Aksoy, 2004). "Kız kısmı çerçidir.” (Üçer, 1998) atasözlerinde ise dilbazdır. "Çerçi gerek halk hikâyelerinde gerekse de fikralarda çoğunlukla bilge, akıllı, kurnaz, becerikli bir tip durumundadır. Bilgeliği okumuş yazmış tahsilli biri olmasından değil, tamamen gezip görmesine bağlı bilgi ve tecrübe birikiminden gelmektedir" (Çelik, 2007: 289). Çelik'in bu ifadesi tespitimiz ile bağlantılı olarak okunabilir. Çerçilere atfedilen bu stereotipler onların günlük yaşam pratikleri içinde mesleklerini icra ederken alış veriş kültürü içinde şekillenen sisteme dâhil olmalarını, ticaret kültürü içinde güçlenmelerini ve meşrulaşmalarını sağlamaktadır.

Çerçilik ile ilgili anlatmalar mesleği icra edenlerin kendi meslekleriyle ilgili düşünceleri ve tutumları hakkında bilgi vermekle birlikte mesleğin icrasında rol alan sözlü kültür insanının bakış açısını da göstermektedir. Çerçiler anlatmalarda her ne kadar kurnaz, uyanık, hazırcevap, dilbaz bir stereotip çizmiş olsalar da onlara atfedilen bu özellikler olumsuz olarak görülmemiştir. Tam aksine onların sözlü edebiyat ürünlerinde yansıma bulan bu özellikleri, geleneksel ticaret biçimi olan çerçiliğin olağan nitelikleri arasında görülmüş ve kabul edilmiştir. Nitekim sözlü kültür ortamında yaşayan kişilerin hayatlarına yenilik, eğlence ve heyecan getirerek uzun yıllar varlık göstermeleri de bu tespiti destekler niteliktedir.

\section{Değiş Tokuştan Süpermarkete Geleneğin Dönüşümü}

Endüstriyel üretimin ekonomin merkezine yerleşmesi, yeni iş alanlarının ve mesleklerin ortaya çıkması ile birlikte üretim ve tüketim dengelerine göre şekillenen geleneksel meslekler, modern teknik uygulamalarla donatılarak endüstriyel meslekler karşısında öncelikli konumlarını hızla yitirmeye başlamı̧̧ır.

Karayolu ağının gelişmesi, ulaşımın daha rahat koşullarda sağlanması, motorlu taşıtların en ücra köşelere bile ulaşabilir olması, kitle iletişim araçlarının yaygınlaşması gibi yaşanan pek çok süreç mesleği değiştirmiştir. Geleneksel çerçilik mesleği 1960’lı yıllardan sonra köylerde ve kasabalarda sabit bakkalların kurulmasıyla başlayan ve bugün hipermarketlere kadar uzanan günümüz modern ticaret anlayışına dönüşmüştür. Bugün; mesleğin son temsilcileri çoğunlukla motorlu araçlarla mesleklerini sürdürmektedir. Mallarını özenle yerleştirdikleri sandıkların yerini araçlarının içinde bulunan 
raf sistemleri almışırı. Gelişlerini okudukları manilerle, eşeklerine sürdükleri kokularla duyuran çerçiler günümüzde seslerini arabalarının klaksonlarıyla ya da hoparlörlerle duyurmaktadır.

Çerçilik, ticari uygulamaları öğrenmenin en iyi yöntemlerinden biri olarak ortaya çıkmıştır. Meslek kuşkusuz günümüz çağdaş yaşamında önemli yeri olan süpermarketlere, çok şubeli mağazalara esin kaynağı olmuştur. Nitekim günümüz büyük mağazalarının oluşumunda çerçilerin başarılı öykülerini görmek mümkündür. Bu bağlamda mesleğe çerçilik ile başlayıp marka haline gelen pek çok şirket bulunmaktadır. Örneğin A. Eriçek, babadan kalan çerçilik mesleğini geliştirerek, bugün Erpiliç markasıyla anılan şirketin kurucusu olmuştur. ${ }^{3}$ Erkilet doğumlu A. Özmen,çocuk yaşta çerçilikle başladığı ticaret hayatını mefruşat alanında isim yapmış bir şirket kurarak, devam ettirmektedir. ${ }^{4}$ R. Mintani 1975 yılında çerçi olarak başladığ1 iş yaşamını Trakya'nın en büyük yerel marketini işleterek sürdürmektedir. ${ }^{5} \mathrm{Bu}$ örnekler ticaret hayatında aktif olarak yer alan pek çok iş adamının hayat hikâyesinden sadece birkaçını oluşturmaktadır.

\section{Sonuç}

Çerçilik, değiş tokuşun var oluşuyla birlikte ortaya çıkmış, geçmişten günümüze farklı adlarla, farklı biçimlerde yaşatılarak varlık göstermiştir. Çerçiler, sözlü kültür ortamında yaşayan bireylerin eğitim, haber, giyim-kuşam, yeme-içme, eğlence gibi pek çok ihtiyacını karşılamıştır. Yeni nesil tüketim alışkanlıkları, teknoloji ve bilgi çağının getirdiği dönüşüm süreci mesleğin zaman içinde farklılaşmasında, biçim değiştirmesinde etkili olmuştur.

Modern kent yaşamında olduğu gibi kırsal alanlarda da geleneksel yöntemlerle mesleği sürdüren çerçiler yok denecek kadar azalmıştır. Günümüzde mesleğin ismini özellikle köy adlarında ${ }^{6}$, soy isimlerde, oyuncakçı, aktar ve "herkes için her şey satan" ve çoğunlukla "çerçi pazarı" şeklinde isimlendirilen alışveriş dükkânlarının tabelalarında görmek mümkündür. En eski ve en yaygın kişisel satı̧̧ yöntemi olarak kullanılan, müşteri ile doğrudan ve sözlü olarak yapılan bu geleneksel ticaretin aktörü olan çerçilerin, her ne kadar mesleğin işlevini, içeriğini, anlamını tam olarak karşılamasa da, günümüzde süpermarket ya da mağazalarda görev yapan "satış temsilcisi, satış danışmanı, satış uzmanı, müşteri temsilcisi vb. gibi” pek çok isimle anılan kişilere dönüştüğü söylenebilir. 
Günümüz ticaretinde, müşterilerin dokunmadan, görmeden alışveriş yapmalarını sağlayan e - ticaret anlayışı ve online ödemelerin gerçekleştirildiği bir süreç yaşanmaktadır. Bu süreçlerin yaşandığ 21 . yüzyılda at ya da eşeklerin çektiği arabalı çerçiler, çağdaş kent yaşamına dâhil olan günümüz insanını adeta "tarihten kopup gelmiş" dedirtecek kadar şaşırtmakta, insanın yüzünde samimi bir tebessüm uyandırmaktadır. Çünkü yaşadığımız devir; heybetiyle bizi kuşatan, içine girdiğimizde ürünleri arasında kaybolduğumuz, pazarlama yöntemleri ve bin bir rengiyle aslında ruhumuzu okşayarak garip bir tüketim çılgınlığına iten, bizleri sarsan modern/ postmodern zamanların, küresel çerçilerin devridir.

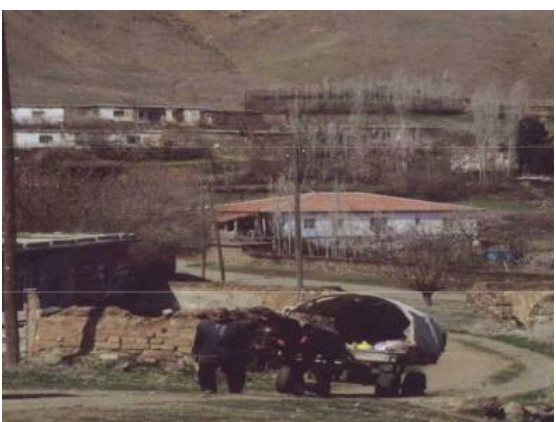

Foto 1: Kırşehir- Çiçekdağ1- Çepni Köyü(1994) Kültür ve Turizm Bakanlığ1 ,Halk Kültürü Bilgi ve Belge Merkezi S1994.1172

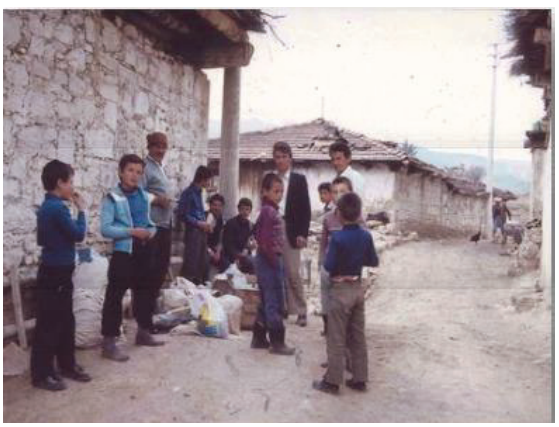

Foto 3: Köyde alı̧veriş yapan çerçi, Manisa- Selendi- Satılmış Köyü(1987) Kültür ve Turizm Bakanlığı, Halk Kültürü Bilgi ve Belge Merkezi S1987.0209

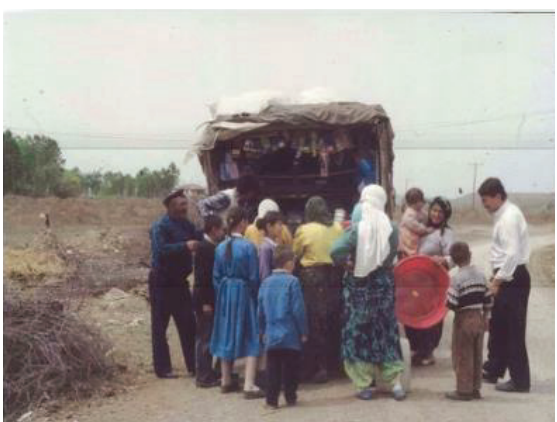

Foto 2: Çankırı- Kızılırmak-Aşağı Alagöz köyü, (1994) Kültür ve Turizm Bakanlığ1, Halk Kültürü Bilgi ve Belge Merkezi S1994.2811

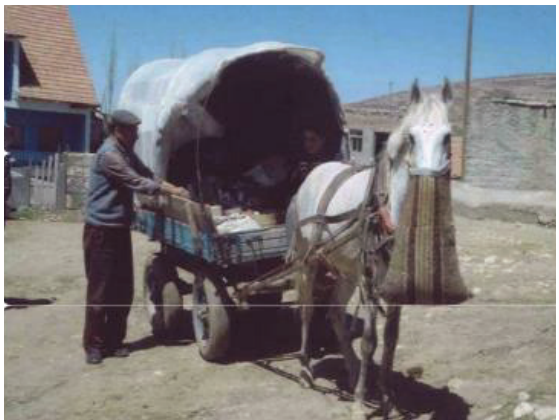

Foto 4: Yozgat, Çayıralan- Çukurören Köyü, (1994) Kültür ve Turizm Bakanlığ1, Halk Kültürü Bilgi ve Belge Merkezi S1994. 2561 


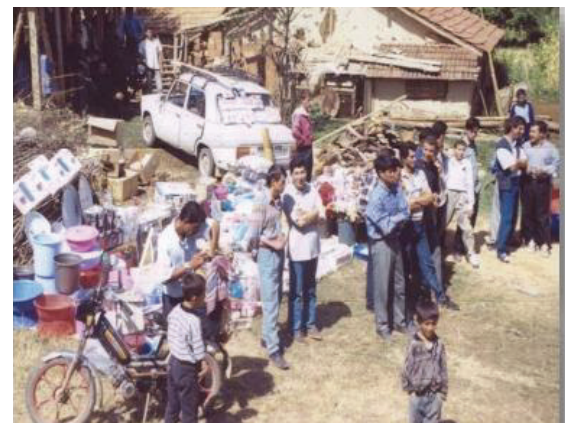

Foto 5: Kı evinin önünde kurulan çerçi sergisi,(1998), Burdur-YeşilovaIğdır Köyü. Kültür ve Turizm Bakanlığ1, Halk Kültürü Bilgi ve Belge Merkezi S1998.1434

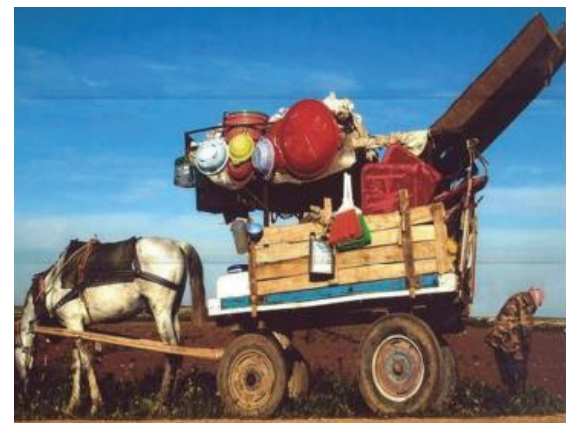

Foto 6: Şanlıurfa,2007,Hüseyin Türkün fotoğraf albümünden yararlanılmıştır.

*Bu makale "Sözlü Kültür Ortamının Gezici Seyyar Satıcıları Çerçiler” adlı basılmamış yüksek lisans tezinden üretilerek 23-25 Mayıs 2017 tarihinde "Sözlü Kültür Ortamının Gezici Seyyar Satıcıları: Çerçiler" adıyla VI. Halk Kültürü Araştırmaları Sempozyumunda sunulmuş ve geliştirilerek makale formatına getirilmiştir.

\section{Sonnotlar}

1 Hikâyenin tamamı için bk. (Görkem, İ. Güney Türkmenlerine Ait Yazıcıoğlu ile Senem Türkülü Hikâyesinin Anlam ve Nesne Dünyası, Türkbilig/Türkoloji Araştırmaları, 2005/9, 40-66)

2 Fikra, 29.03. 2000 tarihli Sabah Gazetesi'nde yer alan Hıncal Uluç’un "Hıncal'ın Yeri” adlı köşesinden alınmıştır.

3 Roportajın tamamı için bk. (www.çiftlikdergisi.com.tr/cercilikten-kanatliimparatorluguna.html, Erişim Tarihi: 04 Şubat 2018)

4 Ayrıntılı bilgi için bk. (Bereket Ö. Ticaretin Altın Kurallarının Yazıldığ 1 Yer- Sultanahmet, 2015:158)

5 Haberin tamamı için bk. (http://www.edirnehaber.org/haber/28826/ cercilikten- trakyanin-en-buyuk-yerel-marketine.html, Erişim Tarihi 25 May1s 2018)

6 Çerçilerin Türkiye'de köy adlarına yansıması ile ilgili ayrıntılı bilgi için bk. (Aykanat, N. "Sözlü Kültür Ortamının Gezici Seyyar Satıcıları Çerçiler” Basılmamı̧̧ Yüksek Lisans Tezi, Gazi Üniversitesi Sosyal Bilimler Enstitisü, Ankara, 2009. 


\section{Kaynaklar}

Aça, Mustafa (2015). "Meslek Folkloru Araştırmaları Tarihine Bir Bakış", Uluslararası Türk Dünyası Kültür Araştırmaları Dergisi, 1 (1), s. 111137.

Aksoy, Ömer Asım (2004). Bölge Ağzzlarında Atasözleri ve Deyimler I-II, Ankara, Türk Dil Kurumu.

Amos, Dan Ben (2006). "Şartlar ve Çevre İçinde Folklorun Bir Tanımına Doğru”, Çev. M. Ekici, Halk Biliminde Kuramlar ve Yaklaşımlar 1 (Yay. Haz.: M. Öcal Oğuz vd.) Ankara: Geleneksel Yayınları, 3. Baskı, s. $27-40$.

Aykanat, Nuray (2009). Sözlü Kültür Ortamının Gezici Seyyar Satıcıları Çerçiler, Basılmamış Yüksek Lisans Tezi, Gazi Üniversitesi Sosyal Bilimler Enstitisü, Ankara.

Bascom, R. W. (2014). "Folklorun Dört İşlevi”, Çev. Ferya Çalı̧. Halk Biliminde Kuramlar ve Yaklaşımlar 2 (Yay. Haz.: M. Öcal Oğuz vd.) Ankara: Geleneksel Yayınları, 3. Bask1, s. 78-81.

Bereket,Özer (2015). Ticaretin Altın Kurallarının Yazıldı̆̆ı Yer-Sultanhamam, İstanbul: TETSİAD yayını, s. 158.

Bilgin, Nuri (1996). İnsan İlişkileri ve Kimlik, İstanbul: Sistem Yayınc1lı.

Çelik, Ali (2007). "Sosyo-Kültürel Boyutuyla Seyyar Satıcılar, Unutulmuş Bir Halk Bilgesi Çerçi ve Erzurum’dan Bir Çerçi Fıkrası”, Uluslararası Türklük Bilgisi Sempozyumu, 25-27 Nisan, Erzurum: Atatürk Üniversitesi Yayını, Bildiriler- 1, s. 283-291.

Dokuzoğlu, Ahmet (2000). Çukurova'dan Fikralar, Adana: Medyasan Matbaacilik.

Dundes, Alan (2006). "Halk Kimdir?", Çev. M. Ekici. Halk Biliminde Kuramlar ve Yaklaşımlar 1 (Yay. Haz.: M. Öcal Oğuz vd.) Ankara: Geleneksel Yayınları, 3. Baskı, s. 11-26.

Duymaz, Ali ve Şahin, H. İ. "Meslek Folkloru Kapsamında Geleneksel Mesleklerdeki Pir İnancı ve Hikâyeleri Üzerine Bir Değerlendirme.” Milli Folklor, 80. s. 33-38.

Eyüboğlu, İsmet Zeki (1995). Türk Dilinin Etimoloji Sözlüğü, İstanbul: Sosyal Yayınları, 3. Baskı. 
Eyüboğlu, E. Kemal (1973). On Ü̧̧üncü Yüzyıldan Günümüze Kadar Şiirde ve Halk Dilinde Atasözleri ve Deyimler, İstanbul: Doğan Kardeş Matbaacilik.

Görkem, İsmail (2005). "Güney Türkmenlerine Ait Yazıcığlu ile Senem Türkülü Hikâyesinin Anlam ve Nesne Dünyası” Türkbilig/Türkoloji Araştırmaları, 2005/9, s. 40-66.

Kaderli-Yapıcı, Zehra (2012). "Kişisel Deneyim Anlatılarının Bağlamsal Çerçevesi: Deneyimlenen, Hatırlanan ve Anlatılan Hayat”, Milli Folklor 94 (Yaz 2012): 207-219.

Koçu, Ekrem Reşad (1958). İstanbul Ansiklopedisi, Neşriyat Kolektif Şirketi Yayınları.

İmançer, Dilek (2005) “Sosyal ve Psikolojik Açıdan Stereotip Kavramının Dil ve Metin Analizinde Kullanımı”, Selçuk İletişim Fakültesi Akademik Dergisi Yayını, C:3, S:3, Temmuz 2005.

Pakalın, Mehmet Zeki (1971). Osmanl Tarih Deyimleri ve Terimler Sözlüğü, İstanbul: Milli Eğitim Bakanlığı Yayınları,3.Cilt.

Sedillot, Rene (2005). Değiş Tokuştan Süpermarkete Tarih Boyunca Ticaretin Öyküsü, Ankara: Dost Kitapevi Yayınları.

Üçer, Müjgan (1998). Atalar Sözü Yerde Kalmaz, Sivas'ta Sözlü Gelenek. İstanbul: Özyılmaz Matbaası.

Yiğit, Turan (1945). "Saray Köyünde Çerçilik” Köy Enstitüleri Dergisi, 1.Cilt, 4. Sayı, Ankara.

\section{Kaynak Kişiler}

K1. Hayrettin Salman. (2007) Tokat, 47, Çerçi.

K2: İhsan Aydın (2007) Ankara, 66, Emekli Öğretmen. K3: Cabbar Karatoprak. (2007) Tokat: 56, Çerçi.

K4:Zeynep Yılmaz.(2007) Ankara, 49, Ev Hanımı.

K5: Hamza Işık.(2007) Tokat, 53, Çiftçi.

K6: Duran Salman. (2007) Tokat, 42, Çerçi. 
Nuray KOMSER 